\title{
Outlook for Federal Fiscal Policy
}

THE 1972 BUDGET on the national income accounts basis (NIA) was programmed in January 1972 to have a full employment deficit of $\$ 4.3$ billion. Instead, the fiscal year ended with a $\$ 4.9$ billion full employment surplus. The $\$ 9.2$ billion shift from deficit to surplus occurred largely as a result of two developments: (1) the unexpected increase in withheld individual income taxes that resulted from the change in the withholding schedules, and (2) the delay in the enactment of general revenue sharing.

For fiscal 1973, the budget document of January 1972 implied another full employment deficit, amounting to $\$ 2.5$ billion. On a unified basis, the federal budget was essentially in balance. As shown in Table 1, legislation subsequently enacted, plus reestimates of interest expenditures, have increased projected federal outlays by $\$ 9.7$ billion in spite of several presidential vetoes. Although the military's request for new obligational authority was reduced by $\$ 5.2$ billion, the decrease in expenditures in fiscal 1973 is estimated to be only $\$ 1.8$ billion, which is offset by increased expenditures for Vietnam of approximately $\$ 1.2$ billion for a net reduction of only $\$ 0.6$ billion in these two categories. Congress reduced the request for funds to equalize military retired pay and took no action either on another retirement proposal or on further increases to finance the volunteer army program. Thus, total defense expenditures should be $\$ 1.3$ billion below last January's request $-\$ 0.9$ billion in purchases of goods and services and $\$ 0.4$ billion in transfer payments. One of the major components of the increase in expenditures is the nearly $\$ 3.3$ billion to make general revenue sharing 


\section{Table 1. Changes Since January 1972 Budget Document in Federal} Expenditures for Fiscal Year 1973

Millions of dollars

\begin{tabular}{|c|c|}
\hline Type of expenditure & Change \\
\hline \multicolumn{2}{|l|}{ Department of Defense } \\
\hline Regular appropriations & $-1,750$ \\
\hline Vietnam & 1,200 \\
\hline Equalization of retired pay & -269 \\
\hline Armed forces retirement ${ }^{\mathrm{a}}$ & -139 \\
\hline Volunteer armya & -356 \\
\hline General revenue sharing & 3,295 \\
\hline Grants to states for social and rehabilitative services & 1,300 \\
\hline Social security (net) & 2,842 \\
\hline Disaster relief & 1,656 \\
\hline Black lung benefits & 969 \\
\hline Railroad retirement benefits & 390 \\
\hline Interest & 400 \\
\hline \multicolumn{2}{|l|}{ Water pollution control } \\
\hline Environmental protection & 250 \\
\hline New construction & $\ldots$ \\
\hline Retroactive payment & b) \\
\hline \multicolumn{2}{|l|}{ Veterans Administration } \\
\hline Increased educational allowances & 372 \\
\hline Increased compensation & 115 \\
\hline School lunch program & 200 \\
\hline Extended unemployment benefits & 300 \\
\hline Student loan programa & 288 \\
\hline Nonsale of assets in stockpile & 301 \\
\hline Drug abuse program & 100 \\
\hline Foreign aid & -370 \\
\hline \multicolumn{2}{|l|}{ Special revenue sharing } \\
\hline Department of Housing and Urban Development & -454 \\
\hline Education $^{\mathrm{a}}$ & -110 \\
\hline Highways $^{c}$ & -220 \\
\hline $\begin{array}{l}\text { Departents of Labor and Health, Education, } \\
\text { and Welfare }\end{array}$ & -700 \\
\hline Other & 40 \\
\hline Total changes & 9,650 \\
\hline
\end{tabular}

Sources: 1973 Budget Scorekeeping Report, Prepared for the Joint Committee on Reduction of Federal Expenditures, 92 Cong. 2 sess., Staff Report 9, Cumulative to October 18, 1972, p. 2 and Table 1; Office of Management and Budget, "Mid-Session Review of the 1973 Budget" (June 5, 1972); The Budget of the United States Government, Fiscal Year 1973; Washington Post, September 15, 1972.

a. Increase in expenditures due to failure to take final action on proposed legislation.

b. $\$ 691$ million, if and when paid.

c. Regular appropriation bill not passed before Congress adjourned. Estimated reduction in expenditures assumes that expenditures will be held to fiscal 1972 levels under a continuing resolution.

d. Labor-HEW appropriation bill was vetoed after Congress adjourned. Estimated reduction in expenditures assumes that expenditures will be held to fiscal 1972 levels under a continuing resolution. 
retroactive to January 1. Revenue sharing for calendar 1972 was originally budgeted at $\$ 4,750$ million, with $\$ 2,250$ million to be paid in fiscal 1972 . In the final legislation this latter amount was raised to $\$ 2,750$ million. In addition, the right to reserve 10 percent of the funds, which was in the original request, was not enacted, adding an additional $\$ 500$ million to the payment. Instead of the $\$ 5.0$ billion included in the original budget request, $\$ 8.3$ billion will be paid to state and local governments under this program in fiscal 1973.

Included in the revenue sharing legislation is a limitation on grants for social and rehabilitative services for welfare recipients to $\$ 2.5$ billion, or $\$ 1.3$ billion above the initial estimate of the federal government's 75 percent share. In fiscal 1970, only $\$ 576$ million was spent; while the 1973 budget estimated expenditures of $\$ 1.5$ billion in fiscal 1972, the total in fact came to just under $\$ 2.0$ billion. These grants pose a considerable problem. The legislative language defining social and rehabilitative services is so loose that a wide range of state-financed programs can qualify. Moreover, the accounting for the funds is so disorganized that the Department of Health, Education, and Welfare (HEW) does not know what the money is used for. ${ }^{1}$ As the states have discovered the program, they have escalated their requests; for example, Texas raised its grant request for fiscal 1973 from $\$ 33$ million in February 1972 to $\$ 179$ million in June; New York from $\$ 438$ million to $\$ 1$ billion; and Mississippi from $\$ 4$ million to $\$ 454$ million-almost the amount of its total expenditure for last year. ${ }^{2}$ Without a limitation, according to a reported estimate by Secretary Elliot L. Richardson, the grant requests would have amounted to $\$ 4$ billion for fiscal 1973 , in contrast with the President's budget request of $\$ 1.2$ billion, and in 1974 would have exceeded $\$ 6$ billion. Distribution of the limited amount will be based on population, and funds can be used for programs concerned with child care, retarded persons, family planning, and help for welfare families. ${ }^{3}$ In effect, the grants have become an additional form of revenue sharing.

Social security benefits are now estimated to exceed last January's estimate by $\$ 2.8$ billion (see Table 2). Of that amount, $\$ 2.1$ billion represents the fiscal 1973 cost of the 20 percent across-the-board increase in benefits enacted in June, and $\$ 700$ million the liberalizations passed in October. The

1. Washington Post, August 9, 1972.

2. Ibid.

3. Washington Post, September 15, 1972. 
Table 2. Increases in Expenditures for Social Security Benefits, Fiscal Years 1973-75

Billions of dollars

\begin{tabular}{lccc}
\hline \multicolumn{1}{c}{ Social security program } & 1973 & 1974 & 1975 \\
\hline Benefits proposed in budget & & & \\
5 percent across-the-board & 2.0 & & \\
Other liberalizations & 2.0 & & \\
20 percent across-the-board increase & $2.1^{\mathrm{b}}$ & 8.0 & 8.0 \\
Liberalizations effective January 1, 1973 & 0.7 & 2.3 & 2.3 \\
Medicare for disabled, July 1, 1973 & $\ldots$ & 2.0 & 2.0 \\
Federalization of adult welfare, January 1, 1974 & $\ldots$ & 0.9 & 1.8 \\
Reduction in medicaid & $\ldots$ & -0.8 & -0.8 \\
$\quad$ Total increase & 6.8 & $\overline{12.4}$ & $\frac{13.3}{13}$ \\
\hline
\end{tabular}

Source: 1973 Budget Scorekeeping Report, Staff Report 9, p. 7, and Congressional Record, daily ed., October 17, 1972, pp. H10205-06.

a. Included in appropriate category below.

b. Amount needed above original budget estimate to finance 20 percent across-the-board increase for three-cuarters of a year.

c. Includes other minor changes in medicare.

January estimates included an allowance of $\$ 4$ billion for the increase in benefits-half for a 5 percent across-the-board increase and half for liberalizations including medicare for the disabled. Although the across-theboard increase has a first-full-year cost of $\$ 8$ billion, the June legislation set the effective date in October; thus the increase will cost only $\$ 6$ billion in fiscal 1973, $\$ 2$ billion above the allowance in the budget. Additional social security liberalizations, including medicare for the disabled and federlization of adult categories of welfare (aged, blind, and disabled), were passed in October. However, the effective dates of these increases are spread out over the next fourteen months.

Table 1 also lists some other programs responsible for large increases in expenditures. One is the result of tropical storm Agnes and similar natural disasters; disaster relief is expected to cost $\$ 1.7$ billion in fiscal 1973. Another is for benefits to coal miners suffering from black lung disease. The railroad retirement legislation extends to its beneficiaries the same 20 percent increase in benefits given to social security recipients. Interest payments are, of course, one of the open-ended appropriations. The revised interest estimate was made in the "Mid-Session Review of the 1973 Budget" by the Office of Management and Budget, released June 5, 1972. The water pollution control bill, enacted over a veto, creates $\$ 24$ billion of new obligational authority, but relatively little of the new construction money will be 
spent in fiscal 1973. The bill does contain provisions to reimburse state and local governments for facilities built before the federal subsidies were available; the reimbursement is estimated at $\$ 691$ million. However, the President indicated in his veto message that even if the veto were overridden he would exercise his authority not to obligate these funds. Veterans' benefits were increased by $\$ 487$ million.

On the other hand, some reductions were made. Foreign aid was reduced by $\$ 370$ million. Sizable reductions in military retirement and pay from the January estimates are likely to occur because Congress either turned down or did not take up several expensive proposals in this area. A highway bill died in conference in the last days of the session.

Late in the congressional session, in light of the substantial additions to outlays recorded above, the House passed a $\$ 250$ billion expenditure ceiling (unified basis) giving the administration complete discretion over where and how deeply to make reductions. But the ceiling ran into considerable opposition in the Senate, basically on the grounds that it would permit the President to eliminate programs or severely reduce their funding. Beyond this, however, was the feeling that, in giving up control over the federal purse, Congress would be yielding to the executive branch its most important prerogative. The Senate exempted veterans' programs, social security and other retirement benefits, welfare, and medicaid from cutbacks; stipulated essentially proportionate reductions among the remaining major categories (including defense); and proposed that no more than 10 percent be cut from any of the functional categories. These limits were unacceptable to the administration and ultimately no ceiling was enacted. However, the final legislation establishes a committee to investigate means for the Congress to control expenditures more effectively and to make mandatory an annual report on impounded funds. The President subsequently vetoed eleven bills. The bills on airport safety, rivers and harbors, rehabilitation and special benefits for the aged were authorization, not appropriation, bills and would not have affected fiscal 1973 expenditures. A pay increase for federal marshals, and increases in veterans' burial and medical benefits, were also vetoed, reducing 1973 outlays by less than ü 100 million. The major reduction in expenditures came from the veto of the Labor-HEW appropriation. Those two departments have been put on continuing resolution-that is, they can continue to spend at last year's rate until their appropriations are enacted. ${ }^{4}$

4. Washington Post, October 28, 1972. 
Adding all the changes to total full employment expenditures of $\$ 253.9$ billion (NIA basis) estimated last January raises the fiscal 1973 total to $\$ 263.6$ billion.

To finance the social security expenditures, the June and October legislation increased the combined old-age, survivors, disability, and hospital insurance (OASDHI) tax rate from 10.4 percent to 11.7 percent effective January 1, 1973, and raised the ceiling on wages subject to the tax from the current $\$ 9,000$ to $\$ 10,800$ in 1973 and to $\$ 12,000$ in 1974 . These changes will push social security tax liabilities for calendar $1973 \$ 10.5$ billion above the amount calculated with the 1972 tax rate and wage ceiling. These actions boosted the net revenue estimated last January by only about $\$ 1$ billion. The budget document had assumed that the increase in the wage ceiling would be made retroactive to January 1972; postponing it until January 1, 1973, curtailed revenue. But raising the tax rate to 11.7 percent (from the 11 percent originally programmed) added to fiscal 1973 revenues. Partial adjustment is assumed for the overwithholding that has occurred, thus lowering 1973 revenues. These various changes have reduced estimated full employment receipts by $\$ 1$ billion-from $\$ 251.4$ billion to $\$ 250.4$ billion. As shown in Table 3, these estimates of revenues and expenditures yield a full employment deficit of $\$ 13$ billion for fiscal 1973.

Even though the reduction in expenditures accomplished by vetoes falls short of the administration's goals, the President still has the power to impound funds. Presidential impoundment of funds arouses a great furor, but there seems to be little question of its legality. There are limitations, however. The government cannot refuse to honor contracts for goods purchased, services performed, or interest due; and no attempt has been made to impound funds in the categorical beneficiary programs, such as social security, unemployment insurance, and veterans' compensation and pensions. But in other areas the executive branch does not have to obligate appropriated funds. President Truman impounded billions of dollars in military funds at the end of World War II and much smaller, but still sizable, amounts of civilian funds at the beginning of the Korean war. ${ }^{5}$ President Johnson ordered a $\$ 5.3$ billion reduction in expenditures in the fall of 1966 that in-

5. Louis Fisher, "Funds Impounded by the President: The Constitutional Issue," George Washington Law Review, Vol. 38 (1969), and Louis Fisher, "The Politics of Impounded Funds," Administration Science Quarterly, Vol. 361 (September 1970), both reprinted in Executive Impoundment of Appropriated Funds, Hearings before the Subcommittee on Separation of Powers, 92 Cong. 1 sess. (1971), pp. 121, 112, respectively. 
volved impounding funds, including $\$ 1.1$ billion in highway obligations, part of which was later released in response to political pressures. Critics of impoundment contend that, in appropriating funds, Congress mandates

Table 3. Full Employment Federal Expenditures and Receipts, National Income Accounts, Fiscal Years 1972 and 1973

Billions of dollars

\begin{tabular}{|c|c|c|c|c|}
\hline \multirow[b]{2}{*}{ Budget item } & \multirow[b]{2}{*}{1972} & \multicolumn{3}{|c|}{1973} \\
\hline & & $\begin{array}{c}\text { Estimate } \\
\text { based on } \\
\text { January } \\
\text { budget } \\
\text { document }\end{array}$ & $\begin{array}{l}\text { Subse- } \\
\text { quent } \\
\text { changes }\end{array}$ & Totala \\
\hline \multicolumn{5}{|l|}{ Expenditures } \\
\hline Purchase of goods and services & 103.1 & 107.1 & -0.7 & 106.4 \\
\hline Defense & 74.3 & 76.7 & -0.9 & 75.8 \\
\hline Nondefense & 28.8 & 30.4 & 0.2 & 30.6 \\
\hline Transfers & 75.7 & 86.5 & 4.8 & 91.3 \\
\hline Domestic & 72.9 & 83.6 & 4.8 & 88.4 \\
\hline Foreign & 2.8 & 2.9 & $\ldots$ & 2.9 \\
\hline Grants-in-aid to state and local governments & 32.1 & 39.5 & 5.2 & 44.7 \\
\hline Interest & 13.5 & 14.8 & 0.4 & 15.2 \\
\hline Subsidies & 5.3 & 6.0 & $\cdots$ & 6.0 \\
\hline Total expenditures & 229.7 & 253.9 & 9.7 & 263.6 \\
\hline \multicolumn{5}{|l|}{ Receipts } \\
\hline Personal taxes & 101.2 & 109.0 & $\ldots$ & 109.0 \\
\hline Corporate profits tax accruals & 44.8 & 48.4 & $\ldots$ & 48.4 \\
\hline Indirect business taxes & 20.1 & 21.8 & $\ldots$ & 21.8 \\
\hline Social security taxes & 63.5 & 72.2 & 1.0 & 73.2 \\
\hline Total receipts & 229.6 & 251.4 & 1.0 & 252.4 \\
\hline \multicolumn{5}{|l|}{ Adjustments } \\
\hline Accelerated withholding ${ }^{b}$ & 5.0 & $\cdots$ & $\cdots$ & -2.0 \\
\hline Adjusted receipts & 234.6 & 251.4 & $\ldots$ & 250.4 \\
\hline Budget surplus or deficit & 4.9 & -2.5 & $\ldots$ & -13.2 \\
\hline \multicolumn{5}{|l|}{$\begin{array}{l}\text { Addendum: adjustment to full employment } \\
\text { expenditures }\end{array}$} \\
\hline Transfers & -2.8 & -0.9 & $\ldots$ & -0.9 \\
\hline Grants & -0.7 & -1.1 & $\ldots$ & -1.1 \\
\hline
\end{tabular}

Sources: Complied from data in The Budget of the United States Government, Fiscal Year 1973; Special Analy'ses of the United States Government, Fiscal Year 1973; Economic Indicators (September 1972); Survey of Current Business, Vol. 52 (July 1972); Table 1 above. Receipts are author's estimates.

a. Updated for congressional and presidential action through October 30, 1972.

b. Results from underestimating the effects of legislation passed in December 1971. 
that they be spent, but in the few cases that have been brought, the courts have upheld the right of the executive not to obligate funds. ${ }^{6}$

The struggle between the President and Congress over impounded funds is essentially political. The decisive appeal is not to legal principles and Court decisions but to constituencies and agency support: "The President can and may withhold expenditure of funds to the extent that the political milieu in which he operates permits him to do so."7

The outlook for expenditures on the national income accounts basis discussed above points toward $\$ 256$ billion for unified budget outlays. ${ }^{\prime}$ Thus, to reach a $\$ 250$ billion level of unified outlays, a reduction of $\$ 6$ billion would be required from the total now in prospect. That reduction would have to be made primarily in the total of $\$ 72$ billion of relatively controllable expenditures, ${ }^{9}$ a decrease of about 8 percent. However, the fiscal year is already almost half over and reductions at an annual rate of 14 to 15 percent would have to be made in the remaining months if the required reduction is to be realized by June 30 .

\section{Prospects for Fiscal Year 1974}

In fiscal year 1974, full employment receipts are likely to rise to more than $\$ 277$ billion. The increase of nearly $\$ 27$ billion in receipts is larger than normal growth in full employment revenues because fiscal 1974 gets the full impact of the increase in the social security ceiling from $\$ 9,000$ to $\$ 10,800$ and in the tax rate from 10.4 percent to 11.7 percent. This tax increase will add approximately $\$ 7.5$ billion to fiscal 1974 receipts.

Estimates for the built-in increases in expenditures for fiscal 1974 are shown in Table 4. The programs included there are those shown in Summary Table 7, "Controllability of Budget Outlays" of The Budget of the

6. Ibid., pp. 113, 124-37.

7. Ibid., p. 132; Fisher is quoting from Arthur S. Miller, "Presidential Power to Impound Appropriated Funds: An Exercise in Constitutional Decision-making," North Carolina Law Review, Vol. 43 (April 1965), p. 533.

8. See Nancy H. Teeters, "The 1973 Federal Budget," Brookings Papers on Economic Activity (111972), p. 222, for the reconciliation between the unified and the NIA budgets.

9. Of the $\$ 246.3$ billion of expenditure estimated in the January budget document, relatively uncontrollable expenditures totaled $\$ 128.2$ billion, and another $\$ 46.3$ billion in outlays was expected from prior-year contracts and pay increases, leaving $\$ 71.8$ billion of relatively controllable outlays. That amount has changed little since January, because additions were largely in open-ended relatively uncontrollable programs. 
United States Government, Fiscal Year 1973-except for housing subsidies, pollution control, military spending, revenue sharing, and the nonrecurring expenditures.

The built-in expenditures consist primarily of open-ended benefit pro-

Table 4. Built-in Increases in Federal Expenditures and Increases Embodied in Requested Legislation, Fiscal Year 1974

Billions of dollars

Source of increase and program

Amount

Built-in increases

Social security

OASDHI/SMI

9.2

Civil service retirement

0.5

Unemployment benefits

0.6

Railroad retirement

0.1

Interest

0.6

Veterans' benefits: pensions, compensation, insurance, and education

0.2

Farm price supports

Medicaid

...

Public assistance

$-0.4$

Food stamp program

1.6

Military retired pay

...

Housing subsidies

0.6

Pollution control

1.0

Department of Defense, other than pay and retirement

1.0

Revenue sharing

3.0

Miscellaneous

0.7

2.0

Allowances for pay increases

Department of Defense

2.7

Other

0.8

Total built-in increases in expenditures

Less: Nonrecurring payments in 1973

Retroactive revenue sharing

Net total

Requested legislation

Family health insurance $\quad 1.1$

Special revenue sharing $\quad 2.8$

Welfare reforma

Total requested legislation

7.6

Source: Brookings budget projection model, author's estimates, and Budget of the United States Government, Fiscal Year 1973, pp. 540-41.

a. Adjusted to reflect federalization of adult categories of welfare. 
grams that can be expected to increase with the ever larger number of people eligible for them. In addition, the built-in increase in social security (OASDHI) includes $\$ 5.5$ billion to reflect the full-year cost of the 20 percent increase in benefits, medicare for the disabled, and other liberalizations. The $\$ 1.6$ billion increase in public assistance includes $\$ 0.9$ billion to cover the cost of federalizing the adult categories.

A substantial expansion in budget authority for pollution control was passed this year, as mentioned earlier, but outlays will come slowly because these are primarily construction funds. In contrast, the housing subsidies, which got under way slowly, are now being spent at or above anticipated rates. The increases in military expenditures, other than for increased pay and retirement costs, are based on the five-year projections of military costs made in a recent Brookings study. ${ }^{10}$

Although the defense appropriation bill reduced obligational authority by $\$ 5$ billion, most of the reduction was achieved by stretching out programs and deliveries of new equipment, and no major program was eliminated. The estimate of the rise in real defense expenditures made in the Brookings study appears still to be valid and $\$ 3$ billion is estimated as the fiscal 1974 cost of the increase in defense expenditures.

Built-in additions to expenditures, including the adjustment in defense, totaled more than $\$ 24$ billion. However, the retroactive payment for revenue sharing should not recur. The net result of this payment and the built-in additions means an increase of approximately $\$ 21$ billion in expenditures for fiscal 1974. Assuming the enacted budget for fiscal 1973, and thus ignoring the possibility of presidential cutbacks, NIA expenditures would then total over $\$ 284$ billion, as shown in Table 5, resulting in a full employment deficit of approximately $\$ 7$ billion for fiscal 1974. That deficit would be enlarged with passage of the programs that so far have been only requested (shown at the bottom of Table 4). Two programs requested by the administration for implementation in fiscal year 1974-family health insurance and special revenue sharing-were not enacted, and probably are slated for reintroduction. Welfare reform was dropped from the social security legislation just before Congress adjourned, but may well be an issue again in the next Congress. If these programs are enacted, an additional $\$ 7.6$ billion would be added to full employment expenditures to bring the 1974 full employment deficit to nearly $\$ 15$ billion. Obviously, the achieve-

10. Charles L. Schultze, Edward R. Fried, Alice M. Rivlin, and Nancy H. Teeters, Setting National Priorities: The 1973 Budget (Brookings Institution, 1972) pp. 81, 415. 
Table 5. Baseline Full Employment Federal Expenditures, Receipts, and Surplus or Deficit, National Income Accounts, Fiscal Years 1973 and 1974 Billions of dollars

\begin{tabular}{|c|c|c|c|c|c|}
\hline Budget item & 1973 & $\begin{array}{l}\text { Built-in } \\
\text { increases }\end{array}$ & 1974 & $\begin{array}{l}\text { Increase } \\
\text { in } \\
\text { requested } \\
\text { legislation }\end{array}$ & $\begin{array}{l}1974, \\
\text { including } \\
\text { requested } \\
\text { legislation }\end{array}$ \\
\hline \multicolumn{6}{|l|}{ Expenditures } \\
\hline Purchases of goods and services & 106.4 & 7.5 & 113.9 & $\ldots$ & 113.9 \\
\hline Defense & 75.8 & 5.7 & 81.5 & $\ldots$ & 81.5 \\
\hline Nondefense & 30.6 & 1.8 & 32.4 & $\ldots$ & 32.4 \\
\hline Transfer payments & 91.3 & 11.2 & 102.5 & 1.1 & 103.6 \\
\hline Domestic & 88.4 & 11.2 & 99.6 & 1.1 & 100.7 \\
\hline Foreign & 2.9 & $\ldots$ & 2.9 & $\ldots$ & 2.9 \\
\hline \multicolumn{6}{|l|}{ Grants-in-aid to state and } \\
\hline local governments & 44.7 & 0.6 & 45.3 & 6.5 & 51.8 \\
\hline Interest & 15.2 & 0.6 & 15.8 & $\ldots$ & 15.8 \\
\hline Subsidies & 6.0 & 1.0 & 7.0 & $\ldots$ & 7.0 \\
\hline Total expenditures & 263.6 & 20.9 & 284.5 & 7.6 & 292.1 \\
\hline \multicolumn{6}{|l|}{ Receipts } \\
\hline Personal taxes & 107.0 & $\ldots$ & 117.5 & $\ldots$ & 117.5 \\
\hline Corporate tax accruals & 48.4 & $\ldots$ & 52.0 & $\ldots$ & 52.0 \\
\hline Indirect business taxes & 21.8 & $\ldots$ & 23.5 & $\ldots$ & 23.5 \\
\hline Social security taxes & 73.2 & $\cdots$ & 84.3 & $\cdots$ & 84.3 \\
\hline Total receipts & 250.4 & $\cdots$ & 277.3 & $\cdots$ & 277.3 \\
\hline Full employment surplus or deficit & -13.2 & $\ldots$ & -7.2 & $\ldots$ & -14.8 \\
\hline
\end{tabular}

Sources: Tables 3 and 4, and author's estimates.

a. Includes pay increases.

ment of a less expansionary budget would require cutbacks in programs or increases in taxes-issues that are bound $t$ be in the forefront of administration planning and congressional deliberations on the budget for the 1974 fiscal yeas. 